\title{
Desiderata i Tidsskrift for Islamforskning
}

"Reformer islamforskningen" lød titlen på en kronik, jeg skrev til Information i 2006 (Magaard 2006a) - samme år, som det første nummer af Tidsskrift for Islamforskning (TIFO) udkom. I dag, ti år efter, vil jeg stadig opfordre til at gentænke flere af de grundlæggende antagelser, som en stor del af den danske islamforskning baserer sig på. Mit empiriske grundlag udgøres af samtlige numre af TIFO fra 2006 til 2015. Som det pointeres i videnskabssociologien, er et tidsskrift aldrig bare en spejling af ny viden, men i høj grad også en spejling af nogle sociale strukturer og hierarkier (Bird 2010). Dermed bliver det en spejling af, hvad man i disse sociale strukturer og hierarkier anser for ikke bare videnskabeligt, men også socialt ønskeligt at fokusere på. I forhold til TIFO kan man spørge, om der i de første ti år af tidsskriftets levetid har manifesteret sig teoretiske grundlæggende antagelser, som der er konsensus omkring, eller som i hvert fald ikke er blevet tilstrækkeligt udfordret, og som med fordel kunne nytænkes?

\section{Research on Islam Repositioned?}

I 2008 udgiver TIFO et temanummer med titlen "Research on Islam Repositioned - New Agendas in the study of Islam and

Tina Magaard, ph.d., er lektor på Institut for Forretningsudvikling og Teknologi, AU. Hendes interesse er at identificere og kortlægge samfundsmæssige og idehistoriske paradigmeskifter. I 1990'erne arbejdede hun med dekonstrutionen af den kristne og platoniske kulturarv i europæisk kontekst, for derefter at undersøge, hvorvidt den islamiske tradition har kendt lignende dekonstruktionsprocesser. Hendes nyeste forskning angår den samfundsmæssige og idehistoriske omstilling fra lineær til cirkulær økonomi. 
Muslims in a politicised research field". Temanummeret udspringer af redaktørernes ønske om at reagere på den (negative) opmærksomhed, islamforskningen har tiltrukket sig op gennem 2000'erne. Ifølge redaktørerne anklages islamforskere uretmæssigt for at "disregard potential links between radicalisation, Islam and terrorism" (Schmidt et al. 2008, 3). Andre bidragydere klager over, at "policy and popular discourse" associerer islam med "danger, threat, and risk", at islamisk fundamentalisme i den offentlige debat beskrives som en "totalitarian ideology with fascist-like features" (Jacobsen 2008, 28), og at medier og politikere stiller spørgsmål som “is Islam detrimental to women's rights, human rights, democratic values? Is Islam a violent religion?” (Schmidt 2008a, 22). Disse kritiske spørgsmål til islamforskningen kunne have været et oplagt udgangspunkt for at gentænke islamforskningens grundlæggende antagelser. Men de fleste bidrag handler mere om at forsvare, hvorfor man fortsætter med at tænke i de samme baner som før. En bidragyder satser endda på, at de ubehagelige spørgsmål snart driver over:

The present political climate around Islam will one day, by the very nature of meteorology, recede, blow over-or, more likely, drift over to occupy the sky over another cluster of public "problems". (Mandaville 2008, 9)

Som den eneste bidragyder opfordrer Thomas Hoffmann til ikke at undgå, men tværtimod at adressere de pinefulde spørgsmål (Hoffman 2008). Denne opfordring er dog sjældent blevet taget op i de følgende numre af TIFO.

\section{Divergerende positioners epistemologiske værdi}

I ovennævnte temanummer, "Research on Islam Repositioned", bliver der sat ord på nogle penible spørgsmål rettet mod islamforskningen (altså hvorvidt nogle versioner af islam kan udfordre pluralisme, liberal tolerance, kvinderettigheder, menneskerettigheder, demokratiske værdier, samt hvorvidt islamismen kan relateres til totalitarisme og sikkerhedstrusler). Men man inviterer ikke de forskere ind, som på "Repositioning”-temanummerets redigeringstidspunkt havde adresseret disse spørgsmål. Blot tre eksempler fra en dansk kontekst: lektor i 
mellemøststudier Lars Erslev Andersen skriver allerede i 2002, at salafismen giver "ideologisk grundlag for væbnet kamp (...) og terrorisme" (Andersen og Aagaard 2002, 62), og at dens "tolkninger af islams fjender og jihad" er "omfattende spredning af et politisk militant budskab" (ibid. 64). Professor i statskundskab Mehdi Mozaffari argumenterer for, at islamismen kan ses som en pendant til de europæiske totalitarismer (2007a; 2007b), og undertegnede havde allerede før 2008 behandlet spørgsmål omkring kvinderettigheder (Magaard 2006b) og menneskerettigheder (Magaard 2008) samt gjort rede for fjendebilleder og voldsforestillinger i islamiske helligtekster, med et oplæg til at diskutere, hvorvidt disse operationaliseres af islamistiske bevægelser (Magaard 2007a).

Bidragyderne til "Research on Islam Repositioned" forholder sig dog ikke til disse eller lignende studier, hvorved læseren ikke bliver præsenteret for en forskningsmæssig behandling af ovennævnte spørgsmål. Fra et videnskabssociologisk synspunkt kan man argumentere, at redaktørerne hermed forpasser en chance for at udvikle deres eget forskningsfelt. Divergerende synspunkter har jo en epistemologisk værdi i kraft af den diskussion, de naturligt vil skabe, ligesom dissidente positioner ofte besidder specifikke data eller indsigt, som går tabt i den konsensus, der udelukker divergerende vinklinger (Solomon 2006). Forhåbentlig vil man i fremtiden i højere grad end tidligere lade divergerende synspunkter komme til udtryk i Tidsskrift for Islamforskning, så alle får mulighed for at skærpe, finpudse og nuancere egne argumenter gennem den kontradiktoriske debat.

\section{Hvad er formålet med islamforskning?}

Indledningsvis kan det være nyttigt at overveje, hvad forskningens formål skal være. Nogle TIFO-forfattere formulerer meget eksplicit deres forsknings formål: Én fremhæver "the need to counter negative stereotypes of Muslims and Islam" (Jacobsen 2008, 29), mens en anden ønsker at "nuancere det stærkt negative billede, som i den politiske og offentlige debat ofte tegnes af muslimer og muslimske minoriteter" (Jeldtoft 2008, 59).

Ønsket om at konstruere et mere positivt billede af muslimer ses af og til i samspil med konstruktionen af et negativt billede 
af ikke-muslimer, hvad enten det er mellemøstlige kristne (Jørgensen 2015), danske institutioner som fængsler (Olsen 2008), skoler (Gilliam 2008; Pedersen 2014) eller statslige myndigheder (Lindekilde 2010). Samtidig adresserer TIFO kun meget marginalt offentlighedens interesse i, hvorvidt nogle versioner af islam rent faktisk kan udfordre pluralisme, liberal tolerance, kvinderettigheder, menneskerettigheder, demokratiske værdier og sikkerhed. Men medieopmærksomheden omkring islam og islamforskning bliver ikke nødvendigvis mindre af, at man minimerer disse spørgsmål. Mandavilles forudsigelse om, at offentlighedens opmærksomhed ville drive over som en sky på himlen, er da heller ikke gået i opfyldelse.

Dette kan muligvis hænge sammen med, hvordan nogle muslimer har valgt at agere i det europæiske samfund. Antallet af udførte samt afværgede jihadistiske terrorangreb i Europa er steget markant (European Police Office 2016, 22-33); jødehadet er kommet til udtryk gennem mord på jøder, alene fordi de er jøder (se nedenstående); satirikere giver udtryk for, at de ikke længere tør gøre grin med islam (Andersson 2015); den økonomiske integration af borgere med mellemøstlig oprindelse halter (Danmarks Statistik 2015), medierne afslører ulovligheder og kvindeundertrykkelse i europæiske moskeer (Braagaard 2016; Channel 4 2007; Channel 4 2008; SVT 2012), og 37,8 \% af danske muslimer ville foretrække, at dansk lov var helt eller delvis baseret på sharia (Johansen og Vibjerg 2015), etc.

Men at læse samtlige numre af Tidsskrift for Islamforskning giver en kuriøs fornemmelse af at skue ind i et univers, hvor ovennævnte sociologiske udvikling aldrig rigtig har fundet sted. Hænger dette mon sammen med ønsket om at modgå negative billeder af islam/muslimer? Hvorvidt risikerer man, at dette formål kommer til at stå i vejen for en forskningsmæssig be handling af væsentlige samfundsmæssige spørgsmål? Hvilke teoretiske rammer kan med fordel fornyes, hvis man vil gentænke islamforskningens formål?

\section{Socialkonstruktivismen i essentialismens tjeneste?}

En af de grundlæggende antagelser, som slår igennem i de fleste TIFO-artikler, og som på intet tidspunkt udfordres, udgøres af den socialkonstruktivistiske tilgang. For eksempel når muslimsk identitet præsenteres som en social konstruktion. Det er 
alle identiteter vel i en vis udstrækning, men i islamforskningskontekst kobles denne overbevisning ofte sammen med en manglende nysgerrighed over for islamiske doktriners mulige betydning for den enkelte muslims valg.

Enkelte bidrag til TIFO udgør undtagelser fra den tendens, såsom Anne Sofie Roalds anmeldelse af Tina Gudrun Jensen og Kate Østergaards bog om konvertitter, Nye Muslimer i Danmark. Møder og omvendelser. Roald (2008) kritiserer, at forfatterne ikke forbinder konvertitternes udtalelser til "de mønstre eller færdige fortællinger", som de forskellige islamiske bevægelser i Danmark tilbyder deres tilhængere, og som giver ekko i konvertitternes fortællinger. Måske skyldes dette, at Jensen og Østergaard ikke har interesseret sig for disse "mønstre og færdige fortællinger" og derfor ikke har kunnet identificere dem i deres datamateriale? Det spørgsmål kan kun forfatterne selv svare på. Men som læser kan man konstatere, at de ikke har interesseret sig for at etablere koblingen.

Koblingen fra det enkelte individs holdninger og handlinger, over islamiske bevægelsers "færdige fortællinger", ned til de islamiske kanoniske tekster som Koranen, Hadith og Sira kan naturligvis være kompleks. Men det ændrer ikke ved, at man især i de mere ortodokse miljøer kan observere ubrudte linjer fra teksterne, gennem religiøse autoriteter og videre til "slutbrugeren”, som antropologen og sociologen møder i deres undersøgelser. I den forbindelse har jeg tidligere advokeret for, at man inddrager ovennævnte islamiske tekster som del af en multikausalistisk analyse (Magaard 2007a). Det betyder ikke, at man går ud fra, at alle muslimer fjernstyres af Koranen, men det betyder, som flere af mine publikationer påviser (Magaard 2009a; Magaard 2011), at de islamiske teksters budskab faktisk kan spille en rolle for nogle muslimers holdninger og handlinger, og at de dermed har sociale, økonomiske, kulturelle og retslige konsekvenser.

At man undersøger disse konsekvenser (samt deres eventuelle kobling til bestemte islamiske bevægelser og bestemte tekstpassager) behøver ikke at betyde, at man skal give slip på den socialkonstruktivistiske ramme. Man skal bare inddrage i sin analyse, at andre kan vælge en essentialistisk brug af Koranen og andre kanoniske tekster. Kender man ikke disse tekster, kan man ikke identificere, hvor de influerer på bestemte respondenters holdninger og handlinger, ligesom man i øvrigt 
heller ikke kan bidrage til at give liberale muslimer redskaberne til at dekonstruere-rekonstruere de religiøse referencer. Ignorerer man teksterne i socialkonstruktivismens navn, risikerer man altså at bidrage til at stadfæste en essentialistisk religionsforståelse i visse miljøer, hvilket jeg vil give eksempler på nedenfor

\section{Socialkonstruktivismens utilsigtede konsekvenser for kvinderettigheder}

Her vil jeg prøve at fokusere på et af de før nævnte "penible" spørgsmål, nemlig hvorvidt nogle versioner af islam rent faktisk kan udfordre kvinderetslige principper. Dette emne behandles kun forholdsvis marginalt i TIFO (Karman 2010; Roald 2014). Men spørgsmålet er, om man i fremtiden bør give spørgsmålet mere bevågenhed? Det ville også forhindre, at man bliver "rendt over ende" af medierne, som det skete, da TV2-dokumentarserien Moskeerne bag sløret afslørede krænkelser af kvinders rettigheder i otte danske moskeer - heriblandt flere mainstream moskeer. Som den efterfølgende offentlige debat viste, kom afsløringerne som en overraskelse for store dele af befolkningen og politikerstanden. Kom de som en overraskelse for danske islamforskere? Hvis nej: Hvorfor har man så ikke udbredt kendskabet til forholdene? Hvis ja: Hvilke spørgsmål er det, man ikke har fået stillet i tide, så man kunne have været på forkant med det, dokumentaren viste?

For eksempel har en af TIFO's tidligere redaktører, Brian Arly Jacobsen, udtalt, at man i stormoskeen i København i høj grad er "tilhængere af demokrati i Danmark og menneskerettigheder" (Theut 2014). Dette står dog i skærende kontrast til TV2's afsløring af, at man samme sted fraråder en voldsramt kvinde at gå til politiet, også hvis hendes mand bliver ved med at slå hende, og understreger over for hende, at hendes mand "selvfølgelig" har ret til at tage en kone nummer to, selv om hun ikke kan acceptere det. Tilhængere af menneskerettigheder? Hvordan kan en af TIFO's tidligere redaktører tage så meget fejl?

Kan det være, at en tilgang præget af socialkonstruktivismen leder forskerens opmærksomhed væk fra doktrinære spørgsmål, som hermed aldrig bliver afdækket? Som Brian Arly Jacobsen 
skriver i introduktionen til TIFO-temanummeret "Islam \& institutioner":

Temanummerets titel antyder, at det er "islam" som en entitet, der påvirker den institutionelle praksis inden for et bestemt område. Det er naturligvis ikke tilfældet, og om der overhovedet findes en samlet betegnelse som "islam", der ensidigt kan udgøre det ideologiske grundlag for en institution er tvivlsomt. (Jacobsen 2008, 3)

Ved at positionere sig således får man måske ikke spurgt tilstrækkeligt ind til, hvorvidt for eksempel islamisk familieret i nogle sammenhænge kunne påvirke institutionel praksis. Kan det eventuelt hænge sammen med, at det i den sociale struktur, TIFO afspejler, er helt gængs at opfatte shari'a som en "ramme, inden for hvilken der er rig mulighed for fortolkninger og modsatrettede positioner" (Lassen, 2007, 1)?

Hvad end bevæggrunden måtte være, er resultatet, at Arly Jacobsen kommer til at forbigå, at der på nogle områder, som for eksempel kvinderettigheder, faktisk er ret udbredt konsensus blandt de lærde, på tværs af islamiske bevægelser, og at den konsensus baserer sig på doktriner udledt af Koranen og hadith (Magaard 2011, 183). Det kan være med til at forklare, hvorfor kvinden i TV2's dokumentar får nærmest enslydende råd i otte ellers meget forskellige moskeer. Som en repræsentant for Minhaj-ul-Qur'an understreger i min moskéundersøgelse fra 2011:

Vi skal være obs på hvor grænserne går, hvor der er rum for fortolkning og hvor der ikke er rum for fortolkning. Det er jo hele tiden noget, vi prøver at give til de unge her. Koranen og Hadith er vores Grundlov i Islam. Reglen er, at hvis du læser en sætning i Koranen, så er det den konkrete betydning først, ikke den metaforiske. Det er det samme, Danmark har lige lavet en Udlændingelov, hvis jeg går ind og siger "det her kan også læses metaforisk" - det dutter ikke. Vi holder os til lovtekstens bogstavelige betydning. (...) Men der, hvor der er rum for fortolkning, der er det meget åbent, der er der selvfølgelig mulighed for at nogen går den her vej, andre den her vej. (Magaard 2011, 82) 
Set på den måde er det altså ikke forkert at sige, at shari’a kan give "rig mulighed for fortolkninger og modsatrettede positioner" - hvis man husker at tilføje, at denne fleksibilitet kun gælder forhold, der ikke nævnes i Koranen og hadith. Denne pointe er væsentlig i forhold til kvinderettigheder, da Koranen og hadith her giver en del konkrete anvisninger. I samtlige moskeer, jeg besøgte, mødte jeg da også konsensus omkring, at "kvindens stilling som defineret af sharia [med afsæt i Koranen og hadith] er bedre for kvinden end ligestilling mellem kønnene, som dette begreb fortolkes i dansk lovgivning" (Magaard 2011, 183).

Det betyder naturligvis ikke, at alle muslimer i Danmark ønsker at ligge under for en bogstavtro brug af Koranen. Men som det fremgår af min undersøgelse At voere muslimsk kvinde i Danmark (2009a), kan man ikke afvise, at den islamiske retstradition har indflydelse langt ud over de personer, som færdes i moskemiljøet. Selv blandt de veluddannede og fagligt dygtige piger, som udgjorde hovedgrundlaget for undersøgelsen, var det kun ganske få, som klart afviste, at Koranens bud skulle stå over deres rettigheder og ligestilling i ægteskabet (Magaard 2009a: 207). Som det fremgår af undersøgelsen, har respekten for islamiske dogmer i nogle muslimske miljøer konkrete, negative konsekvenser for både integrationen på arbejdsmarkedet og den enkelte kvindes mulighed for at nyde godt af de friheder og rettigheder, hun har ifølge dansk lovgivning. De kvinder, som ønskede at nyde godt af disse friheder og rettigheder, kæmpede ofte en ensom kamp (Magaard 2009a).

Man risikerer altså som forsker at komme til at tage parti i en intern muslimsk kulturkamp, hvis man lægger vægt på at fremføre et socialkonstruktivistisk syn på islam og samtidig glemmer at afdække, hvor der blandt islamiske lærde hersker et essentialistisk syn på og brug af islamisk lovgivning. Brian Arly Jacobsens fejlvurdering af stormoskeen er et konkret eksempel på, hvordan socialkonstruktivisme paradoksalt nok kan favorisere aktører med et essentialistisk religionssyn.

\section{Den minoritetsteoretiske tilgangs blinde vinkler}

Ud over den socialkonstruktivistiske framing præges mange af TIFO-artiklerne af minoritetsteoretiske rammer. Der foreligger sågar et temanummer med navnet "Islam og minoriteter", hvor 
man læser udsagn som "At muslimer i Europa er en minoritet, er en commonsense betragtning" (Galal et al. 2010, 3). Men når noget er blevet så commonsense, at ingen sætter spørgsmålstegn ved det, er det måske netop tid at finde de kritiske briller frem?

Man kunne bl.a. starte med at spørge, hvordan personer med muslimsk baggrund opfatter sig selv? Hvor mange af dem definerer sig selv som "minoritet”, hvis de ikke har fået lagt ordet i munden? I min undersøgelse At voere muslimsk kvinde i Danmark (2009a), baseret på eksplorative, dybdegående interviews, som udforskede respondenternes livsverden og selvopfattelse, deltog 37 kvinder med muslimsk baggrund. Ud af disse 37 brugte kun tre begrebet "minoritet" om sig selv eller deres trosfæller. Det var karakteristisk nok tre ressourcepersoner, som dagligt var i kontakt med danske miljøer, hvor minoritets-majoritetstankegangen står stærkt. I øvrigt var de 37 respondenter så forskellige i deres overbevisninger, fra al-Qaeda-tilhængeren til ateisten, at det nærmest ville være symbolsk vold at mase dem ned i samme "minoritetsboks".

I min undersøgelse Religiøs fritidsundervisning for børn og unge blandt muslimske trossamfund i Danmark (2011) deltog 50 muslimske respondenter fra moskémiljøet. Ikke én af dem brugte udtrykket "minoritet" om sig selv. Nogle definerede sig som "danskere", nogle så sig selv som en del af det globale muslimske fællesskab eller specifikke internationale muslimske fællesskaber som shi'a eller hebashi. Dette er helt i tråd med Andreas Lysholt Mathiasens konstatering i en af de eneste artikler i TIFO, som ikke hviler på minoritetsteoretiske antagelser: Han bruger ordet "diaspora", da det i hans datagrundlag ikke er muslimernes egenskab af social eller religiøs minoritet, der fremhæves, "men netop deres relation til andre muslimer over hele verden" (Mathiasen 2012, 98). Dette perspektiv fortjener at blive udforsket videre, som alternativ til de minoritetsteoretiske rammer.

\section{Alternativer til den minoritetsteoretiske tankegang}

I flere af mine egne publikationer har jeg fremlagt, hvordan minoritets-/majoritetstankegangen kan presse individerne ind $\mathrm{i}$ kollektive tilhørsforhold, de ikke nødvendigvis ønsker eller selv 
har valgt, hvorved man favoriserer de mest konservative strømninger i de muslimske miljøer (Magaard 2007b; Magaard 2009a; 2009b). I forsøget på at udvikle alternativer til den minoritetsteoretiske tankegang har jeg i mine sociologiske undersøgelser eksperimenteret med nye vinklinger, bl.a. med afsæt i sociologen Francois Dubets netværksteori. Rent metodisk har jeg støttet mig til Peter Dahler Larsens mætningsmetode, hvor man kortlægger de variationer af holdninger, der findes inden for en given respondentgruppe (Magaard 2009a,15; Magaard 2011,16).

Dette valg af teori og metode viste sig at give udslag i andre resultater end dem, der hidtil havde været gængse i islamforskningen - såsom afdækningen af den dobbeltrolle, som nogle respondenter spillede. Flere af de respondenter, som i interviewene klagede over det danske samfunds manglende respekt for islam, blev selv af andre respondenter udpeget som nogen, der udøvede social kontrol og religiøs mobning over for mere liberalt indstillede muslimer. At man kræver mere respekt for islam, behøver altså ikke at betyde, at man selv respekterer dem, der vælger at praktisere islam mindre ortodokst - ofte tværtimod. Men hverken den dobbeltrolle eller de modsatrettede positioner blandt de muslimske respondenter ville man have fået øje på, hvis man med et minoritetsteoretisk udgangspunkt havde anskuet de muslimske piger som én gruppe og antaget, at stigmatisering og mangel på respekt kun kunne komme udefra. Det er tankevækkende, at lige præcis det religiøse miljø i Gellerupparken, som i en TIFO-artikel præsenteres som offer for det danske samfunds stigmatisering (Lindekilde 2010), af nogle af mine respondenter blev udpeget som et intolerant miljø, der selv stigmatiserede mindre praktiserende trosfæller og udøvede social kontrol af især unge kvinder. I samtaler med islamforskere har jeg af og til mødt den holdning, at det var bedre at fortie den slags end at risikere at give skyts til Dansk Folkeparti men dermed politiserer man jo emnet og underlægger det holdninger og formodninger, som kan stå i vejen for saglige undersøgelser. Fra et etisk synspunkt kan det kritiseres, at man risikerer at lede opmærksomheden bort fra religiøst-sociale mekanismer, som i sidste ende kan sætte nogle borgeres mest basale fysiske sikkerhed på spil. Det gælder ikke kun de muslimske kvinder, som sidder på sikrede krisecentre rundtom i Danmark, men også andre udsatte grupper, som det fremgår af nedenstående. 


\section{Er minoritetsteorierne medskyldige i mord?}

Som del af den minoritetsteoretiske framing fokuserer flere artikler i TIFO på magt- og anerkendelsesproblematikker og fremhæver nogle muslimers følelse af at blive miskendt i det danske samfund (se for eksempel Galal et al. 2010). Til gengæld viger TIFO-forfatterne konsekvent tilbage fra at fokusere på eksempler, hvor muslimer har svært ved at anerkende ikke-muslimer eller decideret spreder had mod dem. Religiøst begrundet kristenhad er et eksempel. En enkelt artikel herom kunne for eksempel have gjort TIFO-temanummeret "Negotiations of Muslim-Christian relations" mere velafbalanceret. Her vil jeg dog fokusere på et fænomen, som er mere entydigt, og som jeg vurderer som værende mere udbredt i muslimske miljøer end had mod kristne, nemlig jødehadet. Dette emne har hidtil været fuldstændig uberørt i TIFO-regi. Der er ellers grund nok til at beskæftige sig med det. Allerede i 2002 advarede en fransk politolog indtrængende om det jødehad, som bredte sig i islamiske miljøer i Frankrig (Taguieff 2002). En rapport fra European Monitoring Centre on Racism and Xenophobia konstaterer i 2003 "serious increase in acts of antisemitism in some parts of Europe" (3). Det konstateres, at der i lande som Frankrig og Danmark er sket et skifte i den typiske gerningsmandsprofil, fra højreekstremister til unge muslimske mænd (ibid.).

Et TIFO-studie med fokus på Nørrebro påkalder sig opmærksomhed i denne sammenhæng (Hussain 2014). Her konkluderes, at "Contrary to media images of Nørrebro (...) residents felt themselves secure and safe in their neighbourhoods" (Hussain 2014, 130). Det fremgår ikke, om jøder har medvirket i undersøgelsen. For kan jøder føle sig "secure and safe” på Nørrebro? I den seneste rapport fra Mosaisk Trossamfunds Afdeling for Kortlægning og Videndeling af Antisemitiske Hændelser (2015) berettes om overfald, chikane og trusler mod jøder i Danmark, og det påpeges, at der særligt er problemer på Nørrebro. Denne situation kulminerede med Omar el-Husseins mord på Dan Uzan i februar 2015, lige efter terrorangrebet på Krudttønden. At 600-70o lokale muslimer mødte op til begravelsen af Omar el-Hussein, rejser spørgsmålet, hvorvidt man i elHusseins lokale miljø på Nørrebro bifalder eller i hvert fald ikke fordømmer drab af jøder (Ritzau 2015). 
I min moskéundersøgelse fra 2011 giver en elev et eksempel på, hvor moderat hendes koranskole-lærer er: Når hun hører andre i sin omgangskreds sige "vi hader jøderne, vi må gerne slå dem ihjel”, så lærer han hende, at man kun skal hade jøderne, ikke slå dem ihjel (Magaard 2011, 170). At valget står mellem at bifalde drab på jøder eller "kun" hade dem, mere end antyder et alvorligt samfundsmæssigt og sikkerhedsmæssigt problem. Men den eneste TIFO-reference til jødehad er et studie i, hvorvidt danskeres nutidige kritiske holdninger over for muslimer kan sammenlignes med jødehadet i 1930'erne (Døving 2010). Det er som udgangspunkt fint at få effektueret en sådan kortlægning, men det giver et uheldigt bias, at man ikke i samme omgang får belyst spørgsmålet om jødehad i nutidige muslimske miljøer. Tilbage i 2003 opfordrede EUMC-rapporten til

new coalitions between politicians, intellectuals, journalists, teachers and many others in order to overcome hate, discrimination and exclusion. Antisemitism can and must be fought jointly to make sure that it never again gains a foothold in Europe. (4)

Siden er det kun gået i den forkerte retning. Modsat EUMC's hensigtserklæring har jødehadet vokset sig stærkere, så det $\mathrm{i}$ Danmark til sidst er endt med, at en Dan Uzan blev myrdet, alene fordi han er jøde. I en europæisk kontekst er dette ikke enestående, som terrorangrebet på det jødiske museum i Bruxelles i 2014 bevidner. Det samme gælder torturdrabet på den franske jøde Ilan Halimi i 2006 eller Mohamed Merahs terrorangreb på den jødiske skole i Toulouse i 2012 eller terrorangrebet på Hyper Cacher-supermarkedet i Paris i 2015. I alle disse tilfælde er jøder blevet myrdet, alene fordi de er jøder. Det er ikke sket i Europa, siden nazismen herskede. Denne situation er jo ikke opstået ud af det blå, som EU-rapporten og Taguieffs forskning bevidner.

Men har sociale strukturer og hierarkier i de europæiske islamforskermiljøer forhindret, at man behandlede problemstillingen i tide? Har nogle bestemte teoretiske rammer skabt et tunnelsyn, som har gjort, at islamforskningen har forpasset chancen for at bidrage til at dekonstruere jødehadet, før det kammede over i mord? Har islamforskningen altså svigtet ved ikke, som EUMC opfordrede til i 2003, at samarbejde med politikere og medier om at bekæmpe jødehadet i muslimske miljøer? 
Har viljen til at fortælle de positive historier taget så meget over, at man mister sin evne til at tænke kritisk? Det er selvfølgelig helt legitimt at beskrive situationer på Nørrebro, hvor sameksistensen fungerer, men det skaber et uheldigt bias, hvis man samtidig vender det blinde øje til reelle problematikker samme sted, såsom jødehadet og dette hads konkrete konsekvenser for jøders sikkerhed. Har minoritetsteorierne stået i vejen for den erkendelse, fordi muslimer så pludselig ikke mere anskues som passive objekter for majoritetens dominans, men som aktive subjekter, som også selv kan udøve magt og endda slå ihjel i en ideologis navn?

Forhåbentlig vil islamforskningen i fremtiden være mere på forkant med, hvad der foregår i visse islamiske miljøer, for ikke at give offentligheden det indtryk, at islamforskerne enten tilbageholder væsentlige oplysninger eller ikke ved, hvad der foregår i de miljøer, de burde være nærmest til at kende. Det betyder selvfølgelig ikke, at alle islamforskere skal beskæftige sig med fænomener som jødehad, men bare at det i et forum som TIFO kunne være godt at inddrage emnet, gerne fra flere vinkler - både af den deskriptive og den normative art.

\section{Kan vi gøre noget anderledes?}

Det er selvfølgelig altid risikofyldt som forsker at bevæge sig ud i normative anbefalinger, men her et forsøg blandt mange mulige: I tråd med min overbevisning om, at muslimer ligesom alle andre er fuldt ud i stand til at tage personligt ansvar og reflektere over deres standpunkter og historiske arv, foreslog jeg i min kronik fra 2006 det samme, som jeg ville foreslå i dag: at man i skolerne behandler både kristent og muslimsk jødehad og udøver

parallel religionskritik af såvel islam som kristendom (...) da fjendtlighed over for jøder er direkte begrundet $\mathrm{i}$ de religiøse helligtekster. Undlader man at etablere paralleller som de ovennævnte, straffer man ikke kun de jøder, som i Europa er ofre for muslimsk intimidering og vold, men også muslimerne selv.

Min pointe er, at man fastholder muslimer på et infantilt niveau, hvis man ikke forventer samme evne til selvkritisk og religions- 
kritisk refleksion hos muslimer, som man forventer hos alle andre.

I den forbindelse nytter det ikke, at man i socialkonstruktivismens navn viger tilbage fra at røre ved de islamiske tekster. Disse tekster indeholder et arsenal af jødefjendtlige udsagn og fortællinger om, hvordan Muhammad fordrev eller myrdede de jøder, som ikke ville underkaste sig (Magaard 2006b). Disse fortællinger genfindes i noget af det undervisningsmateriale, der bruges i islamiske miljøer i Danmark i dag (Magaard 2011, 172). Pointen er her ikke at sige, at disse tekster er hele forklaringen på jødehadet, men at situationen er alvorlig nok til, at vi bør vende alle sten. Hvis islamistisk ideologi og kanoniske tekster spiller bare en lille rolle i udbredelsen af jødehadet, må de nødvendigvis underkastes et kritisk blik. Man kan ikke dekonstruere noget, man ikke ved hvad er, og så længe man ikke går til det tekstuelle korpus med dette kritiske blik, vil en essentialistisk læsning af samme korpus kunne brede sig uhindret.

\section{Afsluttende bemærkninger}

Der hviler i disse år et særligt ansvar på islamforskningen. Den offentlige interesse for islamforskningen skyldes jo blandt andet, at vi i dag overværer konflikter af ganske alvorlig karakter, hvor islam af gerningsmændene udpeges som deres primære motivationsfaktor. Det er forståeligt, at man som islamforsker kan have et ønske om at opveje dette konfliktbillede med positive historier om islam. Men samtidig bør det ønske aldrig stå i vejen for, at man stiller nogle af de svære spørgsmål: om nogle versioner af islam udfordrer pluralisme, liberal tolerance, kvinderettigheder, menneskerettigheder, demokratiske værdier, samt hvorvidt islamismen kan relateres til totalitarisme og sikkerhedstrusler. Disse emner har kun været meget marginalt berørt i Tidsskrift for Islamforskning indtil nu. At adressere spørgsmålene ville kunne skabe et meget mere dynamisk rum i tidsskriftet, da inddragelsen af divergerende vinklinger netop ville opmuntre alle til at skærpe, finpudse og nuancere egne argumenter gennem den kontradiktoriske debat. 
Litteratur
Afdeling for Kortlægning og Videndeling af Antisemitiske Hændelser. 2015. Rapport om antisemitiske hoendelser $i$ Danmark 2014. Mosaisk Trossamfunds Sikkerhedsorganisation.

Andersen, Lars Erslev og Jan Aagaard. 2002. Den afghanske forbindelse. Afghanistanveteraner, al-Qaida-netvaerk og den globale terrorisme. København: Mellemfolkeligt Samvirke.

Andersson, Mikkel. 2015. "Ytringsfriheden er altså knægtet, hr. Lidegaard." I Politiken, 11. januar 2015, politiken.dk/debat/ profiler/mikkelandersson/ ECE2507070/ytringsfriheden-eraltsaa-knaegtet-hr-lidegaard/ Bird, Alexander. 2010. "Social knowing: the social sense of 'scientific knowledge'." I Philosophical Perspectives 24(1): 23-56.

Braagaard, Natali. 2016.

"Moskeerne bag sløret: Få overblikket over TV 2's afsløringer," 3. marts nyheder.tv2. $\mathrm{dk} /$ samfund/2016-03-03moskeerne-bag-sloeret-faaoverblikket-over-tv-2safsloeringer

Channel 4. 2008. Dispatches. Undercover Mosque: The Return. youtube.com/watch?v=njRKa XoORuI

- 2007. Dispatches. Undercover Mosque. youtube.com/ watch?v=kJk_AiK-4No

Danmarks Statistik. 2015. Indvandrere i Danmark 2015.

Døving, Cora Alexa. 2010. "AntiSemitism and Islamophobia: A Comparison of Imposed Group Identities." I Tidsskrift for Islamforskning. Islam og minoriteter. 4 (2).
European Monitoring Centre on Racism and Xenophobia. 2003. Manifestations of Antisemitism in the EU 2002-2003.

European Police Office. 2016. European Union Terrorism Situation and Trend Report (TESAT) 2016.

Galal, Lise, Monique Hocke og Iram Khawaja. 2010. "Introduktion: Muslim og minoritet". I Tidsskrift for Islamforskning. Islam og minoriteter 4(2).

Gilliam, Laura. 2008. "Svinekød, shorts og ballade. Børns forståelse af den danske og den muslimske identitet i skolen". I Tidsskrift for Islamforskning. Islam \& uddannelse 3(3).

Hoffmann, Thomas. 2008. "Concordia Discors or Teach the Conflict. Reflections on the Validity and Heuristics of Scholarly Conflict." I Tidsskrift for Islamforskning 3(2). Hussain, Mustafa. 2014. "Muslims in Copenhagen: Social Cohesion or a Parallel Society? Results from an Empirical Survey 200809." I Tidsskrift for Islamforskning. "Public Islam" and the Nordic Welfare State: Changing Realities? 8(1). Jacobsen, Brian Arly. 2008. "Introduktion: Islam \& institutioner." I Tidsskrift for Islamforskning. Islam \& institutioner 3(1).

Jacobsen, Christine. 2008. "Theory and Politics in Research on Muslim immigrants in Norway." I Tidsskrift for Islamforskning $3(2)$.

Jeldtoft, Nadia. 2008. “Andre muslimske identiteter: et studie af ikke-organiserede muslimske minoriteter i Danmark.” I Tidsskrift for Islamforskning. Islam \& Institutioner 3(1). 
Johansen, Martin og Thomas

Vibjerg. 2015. "4 af 10 muslimer

i Danmark: Lovgivningen skal

bygge på Koranen.” I Jyllands-

Posten 18. oktober. jyllands-

posten.dk/protected/premium/

indland/ECE8125408/4-af-10-

muslimer-i-Danmark-

Lovgivningen-skal-bygge-

p\% $3 \% \mathrm{~A}_{5}$-Koranen/

Jørgensen, Anne Rosenlund. 2015.

"Reframing Interfaith Boundary

Crossing and Maintenance:

Middle Eastern Christians'

Narratives on Intimacy with

Muslims." I Tidsskrift for

Islamforskning. Negotiations of

Muslim-Christian relations 9(2).

Karman, Karen-Lise Johansen.

2010. "Fatwaer og forandringer:

Islamisk lovpraksis i Vesten.” I

Tidsskrift for Islamforskning.

Sharî'a i praksis: fatwa, forbrug

og feminisme 4(1).

Lindekilde, Lasse. 2010.

"Forebyggelse af radikalisering, miskendelse og muslimsk minoritetsidentitet." I Tidsskrift for Islamforskning. Islam og minoriteter 4(2).

Magaard, Tina. 2011. Religiøs fritidsundervisning for børn og unge blandt muslimske trossamfund i Danmark. Rapport udarbejdet for Integrationsministeriet.

- 2009a. At vore muslimsk kvinde i Danmark. Rapport udarbejdet for Ligestillingsafdelingen under Velfærdsministeriet.

- 2009b. "Multikulturalisme og sekularisme: To vinkler på terrorforebyggelse og integration." I Tonny Brems Knudsen, Jørgen Dige Pedersen og Georg Sørensen (red.): Danmark og de fremmede: Om mødet med den arabisk-muslimske verden, 95-
120. København: Hans Reitzels Forlag.

- 2008. "Gudløse i den islamiske verden.” I Malene Busk og Ida Crone (red.): Gudløs! Religionskritik i dag. København: Tiderne skrifter.

- 2007a. "Fjendebilleder og voldsforestillinger i islamiske grundtekster." I Mehdi Mozaffari, Hans-Jørgen Schanz og Mikkel Thorup (red.): Totalitarisme: venskab og fjendskab, 213-238. Aarhus: Aarhus Universitetsforlag.

- 2007b. "Multikulturalisme og sekularisme.” I Kvan 79: 66-73.

- 2006a. "Reformér islamforskningen.” I Information, 29. november.

- 2006b. "Tariq Ramadans reform. Euro-islam eller Euroislamisme?" I Kritik 180.

Mandaville, Peter. 2008. "Introduction: Secular criticism and the politics of studying Islam." I Tidsskrift for Islamforskning 3(2).

Mathiasen, Andreas Lysholt. 2012. "Ummaen, ungdommen og fordringen om enhed og reform: En analyse af den arabiske fredagskhutba i Det Islamiske Trossamfund." I Tidsskrift for Islamforskning. Muslimer $i$ transnationalitet 6(1).

Mozaffari, Mehdi. 2007a. "Islamisme og totalitarisme." I Kritik 180.

Mozaffari, Mehdi. 2007b. "What is Islamism? History and definition of a concept." I Totalitarian Movements and Political Religions 8(1): 17-33.

Olsen, Jon Alix. 2008.

"Konvertering til islam i danske fængsler - vejen ud af kriminalitet eller ind $\mathrm{i}$ radikalisering?" I Tidsskrift for

Islamforskning. Islam \&

institutioner 3(1).

Pedersen, Marianne Holm. 2014.

"Den private religion:

Fortolkninger af muslimske børns religiøse tilhørsforhold i en dansk folkeskole." I Tidsskrift for Islamforskning. Muslimske børn $i$ den 'sekulcere' danske folkeskole $8(2)$.

Ritzau. 2015. “600-700 mødte op til Omar Ebdel Hamid ElHusseins begravelse." DR Nyheder, 20. februar, dr.dk/ nyheder/indland/6oo-70omoedte-op-til-omar-ebdelhamid-el-husseins-begravelse Roald, Anne Sofie. 2014. "The Discourse of Multiculturalism:

An Obstacle to Cultural Change?" I Tidsskrift for Islamforskning. "Public Islam" and the Nordic Welfare State: Changing Realities? 8(1). - 2008. "Anmeldelse: Tina Gudrun Jensen og Kate Østergaard. Nye Muslimer $i$ Danmark. Møder og omvendelser. Forlaget Univers, Højbjerg, 2007. 232 sider.” I Tidsskrift for Islamforskning. Islam \& institutioner 3(1). Schmidt, Garbi. 2008a. "From Granting the Right (?!) Answers to Posing Odd Questions: Perspectives on Studying and Presenting Muslim Minorities in a Politicized, Western Context." I Tidsskrift for Islamforskning 3(2). Schmidt, Garbi et al. 2008.

"Research on Islam Repositioned - New Agendas in the study of Islam and Muslims in a politicised research field." I Tidsskrift for Islamforskning 3(2). 
Solomon, Miriam. 2006.

"Groupthink versus The Wisdom of Crowds: The Social

Epistemology of Deliberation and Dissent." I The Southern Journal of Philosophy 44(S1): 28-42.
SVT. 2012. Uppdrag Granskning. Bakom fasaden i svenska moskéer. youtube.com/watch $? \mathrm{v}=\mathrm{f} 7 \mathrm{Y} \_\mathrm{xfeTIVs} \& f$ eature =youtu.be

Taguieff, Pierre. 2002. La Nouvelle judéophobie. Paris: Fayard Mille et une Nuits.
Theut, Nanna Lodberg. 2014. "Forsker: Problematisk at politikere ikke bakker op om stormoske." DR Nyheder, 16. juni. dr.dk/nyheder/regionale/ hovedstadsomraadet/forskerproblematisk-politikere-ikkebakker-op-om-stormoske 